\title{
EFFECT OF $\kappa$-CARRAGEENAN AND NaCl ON THERMAL PROPERTIES OF FROZEN SURIMI PREPARED FROM ADRIATIC PILCHARD
}

\author{
D. KOVAČEVIC ${ }^{\mathrm{a}}$ and Ž. KURTANJEK ${ }^{\mathrm{b} *}$ \\ ${ }^{\text {a} F a c u l t y ~ o f ~ F o o d ~ T e c h n o l o g y, ~ U n i v e r s i t y ~ o f ~ O s i j e k, ~ F . ~ K u h a c ̌ a ~ 18, ~ H R-31000 ~ O s i j e k . ~ C r o a t i a ~}$ \\ ${ }^{\mathrm{b}}$ Faculty of Food Technology and Biotechnology, University of Zagreb, \\ Pierottijeva 6, HR-10000 Zagreb. Croatia
}

(Received: 6 December 2000; accepted: 4 June 2001)

\begin{abstract}
Samples of surimi were prepared under laboratory conditions from Adriatic pilchard (Sardina pilchardus). Water content in surimi was $81.5 \%$ before mixing with $\mathrm{NaCl}$ and $\kappa$ carrageenan, which were added in the range of mass fraction from 0 to $10 \%$. Relative apparent specific enthalpy $(\bar{H})$, initial freezing point $T_{i}$, density $\rho$ and thermal conductivity $k$ of surimi in the temperature range from $-25^{\circ} \mathrm{C}$ to $10^{\circ} \mathrm{C}$ were determined by differential thermal analysis (DTA), gravimetric method and line-heat source technique, respectively. For determination of relative apparent specific enthalpy $(\bar{H})$ the mathematical model of enthalpy based on orthogonal collocation approximation of DTA was applied. Redistributions of apparent enthalpy in the freezing range as functions of mass fractions of added substances were determined. Increase of mass fraction of added substances resulted in the increase of mass fraction of bound (unfreezable) water and lowered initial freezing point $T_{i}$, which has effects on the decrease of thermal conductivity $k$ and increase of apparent specific enthalpy $(\bar{H})$ in the temperature range from $-25^{\circ} \mathrm{C}$ to $T_{i}$. This effect was more pronounced for samples where surimi was mixed with $\mathrm{NaCl}$.
\end{abstract}

Keywords: thermal properties, frozen surimi, $\kappa$-carrageenan, $\mathrm{NaCl}$

Mathematical models of thermal properties of food are important for the determination of process parameters, design of process units, development of new technologies, and are necessary for the application of numerical methods for determining heat transfer in frozen foods. Thermophysical properties of food can be determined experimentally or estimated from mathematical models which are functions of temperature and food composition (especially water content). There are various methods for the experimental determination of thermal conductivity, which may be generally classified as steady state and transient methods (TAIT \& HILLS, 1964).

* To whom correspondence should be addressed.

Fax: +385 14836 083; tel.: +385 14605 294; E-mail: zkurt@mapbf.pbf.hr 
Due to experimental problems associated with steady state methods, described by REIDY and RIPPEN (1971), for the determination of thermal conductivity of food the line-heat source technique is applied most frequently. The line-heat source technique measures thermal conductivity, assuming unsteady-state heat conduction from an infinitely long line-heat source immersed in an infinite and homogeneous medium. The theoretical bases of the method are given by Hooper and Lepper and Nix and coworkers (SWEAT \& HAUGH, 1974). For small samples of frozen food the thermal conductivity probe constructed by SWEAT (1986) is used most often. To apply this method for foods in the temperature range below $T_{i}$, two conditions must be met: linearity of the temperature versus $\ln$ (time) plot must be satisfied and temperature increase after heating must be limited to assure measurement at the correct temperature and to minimize the effect of latent heat of fusion (WANG \& KOLBE, 1990). Since the construction of the probe is not yet standardised, the relation between the two conditions and the probe design to minimise the difference between theoretical and experimental conditions is still subject to numerous investigations (MURAKAMI et al., 1996). This consideration resulted in the formation of an ad-hoc committee of the North Central Regional Project (NC-136) to address the issue of probe design (MURAKAMI et al., 1995). For determining thermophysical properties $\left(T_{i}, H, c_{\mathrm{p}}\right)$ techniques of differential scanning calorimetry (DSC) and differential thermal analysis (DTA) are applied, which are according to "ICTA" (Nomenclature Committee of the International Confederation for Thermal Analysis) methods based on change of apparent enthalpy (FINDLAY \& BARBUT, 1990). DTA is commonly used as a method for determination of phase change temperatures, degree of sample purity, thermal stability and for identification of chemical or biochemical reactions during heat treatments (CUNNINHAM \& WILBURN, 1970). Since the DTA method is not standardised (geometry and material of measurement cell, reference substance, experimental conditions) it is considered as a semiquantitative technique, opposite to DSC, which is an accurate quantitative method. However, analysis of DTA curve by application of heat balance by the parabolic partial differential equation provides quantitative determination of heat (enthalpy), which is released or absorbed during the first and second order phase changes (CUNNINHAM \& WILBURN, 1970).

In this work, for the determination of thermophysical properties of surimi samples mixed with $\mathrm{NaCl}$ and $\kappa$-carrageenan, a laboratory apparatus was constructed for differential thermal analysis (DTA) and for determining thermal conductivity with a thermal conductivity probe. A numerical method based on orthogonal collocations for approximating the partial differential equation for interpretation of DTA curve is derived. Measurements were performed in the temperature interval from $-25^{\circ} \mathrm{C}$ to $5{ }^{\circ} \mathrm{C}$. In order to derive mathematical models, measured values of thermophysical properties were correlated with mass fractions of added substances. The results were validated by available literature data. 


\section{Materials and methods}

\subsection{Materials}

Surimi samples were prepared in laboratory from Adriatic pilchard (Sardina pilchardus) according to the technique by LEE (1984) with details given by SYCH and co-workers (1990). Samples were divided into two groups and mixed with: a) $\kappa$ carrageenan and b) $\mathrm{NaCl}$. Mass fractions were in the range from 0 to $10 \%$ determined as percent of total mass. Moisture content was $81.5 \%$ determined by the A.O.A.C. method (1980) for meat products before addition of the added components. Total proteins mass fraction was $16.3 \%$ determined with $1 \mathrm{~g}$ samples by Kjeldahl method; (Kjeltec System, model 1002 Distilling Unit, Tecator Inc., Boulder, Colorado, U.S.A). Samples were packaged in polyethylene bags and quickly frozen in liquid nitrogen and stored at $-25^{\circ} \mathrm{C}$. Average storage time was 6 weeks before experimental treatment.

As a reference substance for DTA measurement, $30 \%$ water solution of $\mathrm{CaCl}_{2}$ was used. Distilled water was used as a calibration substance for correcting of initial freezing point and for the thermal conductivity probe.

\subsection{Methods}

Density of samples above initial freezing point $T_{i}$ was determined experimentally by gravimetric method. A known mass (ca. $5 \mathrm{~g}$ ) of sample (at temperature of $24.2 \pm 1{ }^{\circ} \mathrm{C}$ ) was added to a $60 \mathrm{ml}$ volumetric flask which was filled to volume with distilled water $\left(22^{\circ} \mathrm{C}\right)$. Density was calculated using the following equation:

$$
\rho=\frac{m}{60-V}
$$

where $\rho\left(\mathrm{g} \mathrm{ml}^{-1}\right)$ is density, $m(\mathrm{~g})$ is mass of sample; $V(\mathrm{ml})$ is volume of water added (procedure recommended for meat samples (SZCZESNIAK, 1983)). The procedure was completed within $30 \mathrm{~s}$, and any moisture absorption by the sample was minimised.

Thermal conductivity was determined by the line-heat source technique by a thermal conductivity probe having a design described by SWEAT (1986). The probe was obtained from Sweat's laboratory at Texas A\&M University, Department of Agricultural Engineering. The measurement system for on-line data acquisition and software for statistical evaluation of thermal conductivity were constructed and developed at the Faculty of Food Technology and Biotechnology, University of Zagreb, Croatia (KOVAČEVIĆ \& KURTANJEK, 1995).

In the same laboratory DTA apparatus was constructed (KovAČEvIĆ \& KURTANJEK, 1993) and used for measurement of initial freezing point and determination of relative apparent specific enthalpy in the freezing range. 


\subsection{Evaluation methods}

Above initial freezing point $T_{i}$ densities of samples were experimentally determined by gravimetric method, and below $T_{i}$ by Levy's equation (2), as reported by SUCCAR (1985):

$$
\rho=966.33 \cdot\left[0.882+\left(T_{i}-T\right)\right] /\left[0.836+\left(T_{i}-T\right)\right]
$$

Experiments for measurement of thermal conductivity were conducted in the temperature range from $-25{ }^{\circ} \mathrm{C}$ to $10{ }^{\circ} \mathrm{C}$ at $2.5^{\circ} \mathrm{C} \mathrm{h}^{-1}$ rate of thawing. Impulses were applied in the power range from 2.25 to $4.2 \mathrm{~W} \mathrm{~m}^{-1}$. Duration of impulses ranged from 30 to $60 \mathrm{~s}$. Powers applied were lower than those used by SWEAT and HAUGH (1974) and WANG and KOLBE (1990), which was enabled by use of high sensitivity instrument amplifier and accurate A/D conversion. Low energy of impulses resulted in reduced disturbance of distribution of unfrozen water in samples. Lower power was applied in the temperature range close to initial freezing points. Maximum amplitude in temperature was restricted to $0.8^{\circ} \mathrm{C}$ in the temperature range below $-10{ }^{\circ} \mathrm{C}$ and $0.4{ }^{\circ} \mathrm{C}$ in the range up to the initial freezing points. For each sample about 40 experiments were performed and in each experiment about 400 data points were taken in the range of linear temperature increase. A measurement system for determining thermal conductivity, which enables one-dimensional treatment of heat transfer was designed. For determining thermal conductivity $k$ from experimental data obtained by the method of line-heat source, a mathematical model of least squares in the linear range of temperature was applied (KOVAČEVIĆ \& KURTANJEK, 1995), which is:

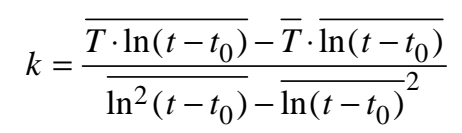

where $t(\mathrm{~s})$ is time; $t_{0}(\mathrm{~s})$ is initial time.

DTA measurements of surimi samples mixed with the added substances (total 21 samples) were conducted in the temperature range from -25 to $5{ }^{\circ} \mathrm{C}$. Each DTA diagram is corrected only for constant error of $+0.045^{\circ} \mathrm{C}$, which was determined from calibration with distilled water. The design of the DTA apparatus is in agreement with assumptions on which the mathematical model for the quantitative determination of apparent enthalpy is applied. The geometry of the test chambers enables onedimensional treatment of the heat transfer process. Slow rate of temperature increase, $15^{\circ} \mathrm{C} \mathrm{h}^{-1}$, makes quasi-steady state approximations applicable, and gives well defined and reproducible DTA diagrams. 
Apparent enthalpy is determined from DTA curves in intervals of $40 \mathrm{mK}$ as proposed by KOVAČEVIĆ and KURTANJEK (1993) which has the discrete form given by:

$$
\begin{gathered}
H_{\mathrm{k}+1}=H_{\mathrm{k}}+\frac{k_{\mathrm{s}}\left(T_{\mathrm{s}}\right)}{\rho_{\mathrm{s}}\left(T_{\mathrm{s}}\right) \cdot \alpha\left(T_{\mathrm{r}}\right)} . \\
\cdot\left[T_{\mathrm{r}, \mathrm{k}+1}-T_{\mathrm{r}, \mathrm{k}}-\frac{4 \cdot \alpha\left(T_{\mathrm{r}}\right)}{R^{2}} \cdot D T A_{\mathrm{k}} \cdot \Delta t\right]
\end{gathered}
$$

where $\rho_{\mathrm{S}}\left(\mathrm{kg} \mathrm{m}^{-3}\right)$ is density of sample; $k_{\mathrm{S}}\left(\mathrm{W} \mathrm{m}^{-1} \mathrm{~K}^{-1}\right)$ is thermal conductivity of sample; $T_{\mathrm{S}}\left({ }^{\circ} \mathrm{C}\right)$ is temperature of sample; $T_{\mathrm{r}}\left({ }^{\circ} \mathrm{C}\right)$ is temperature of reference substance; $R(\mathrm{~mm})$ is radius of a test chamber; DTA $\left({ }^{\circ} \mathrm{C}\right)$ is difference between temperature of sample and reference; $\mathrm{k}$ and $\mathrm{k}+1$ is sampling index; $\Delta t(\mathrm{~s})$ is sampling period. For the calculation the following parameters are required: thermal diffusivity of reference substance, thermal conductivity and density of samples and continuous signals for DTA and reference temperature. The zero of relative apparent specific enthalpy is set at $T=-25^{\circ} \mathrm{C}$. Thermal diffusivity of the reference substance as function of temperature was correlated from data by IBELE (1973):

$$
\alpha(T)=0.1323-3.046 \cdot 10^{-4} \cdot T
$$

\section{Results and discussion}

In the temperature range above initial freezing point, based on 5 replicate measurements, average value of $\rho=1019 \mathrm{~kg} \mathrm{~m}^{-3}$ was determined. Values of $\rho_{\mathrm{s}}\left(T_{\mathrm{s}}\right)$ in the equation for apparent enthalpy (4) were determined by equation (2).

Thermal conductivities were determined by linear regression for the temperature range corresponding to (3), and linearity was checked by linear coefficient of determination, which was in all experiments in the range $r^{2}=0.97-0.99$. On Fig. 1 results of surimi thermal conductivity measurement with $8 \% \quad \kappa$-carrageenan concentration are presented. As it can be observed on Fig. 1, values of $k$ at temperatures slightly below the $T_{i}$ were not determined. This was due to the fact that disturbance of sensitive phase equilibrium by heat impulses from the line-source method can not be neglected. This is the temperature range in which large changes of latent heat and thermal diffusivity occur. A numerical solution of the partial differential equation may be used to evaluate how apparent specific heat affects the conductivity measurement, and to correct the error, as suggested by Schwartzberg. Another way is to use a steady state measurement technique such as a guarded hot plate (WANG \& KOLBE, 1990). 


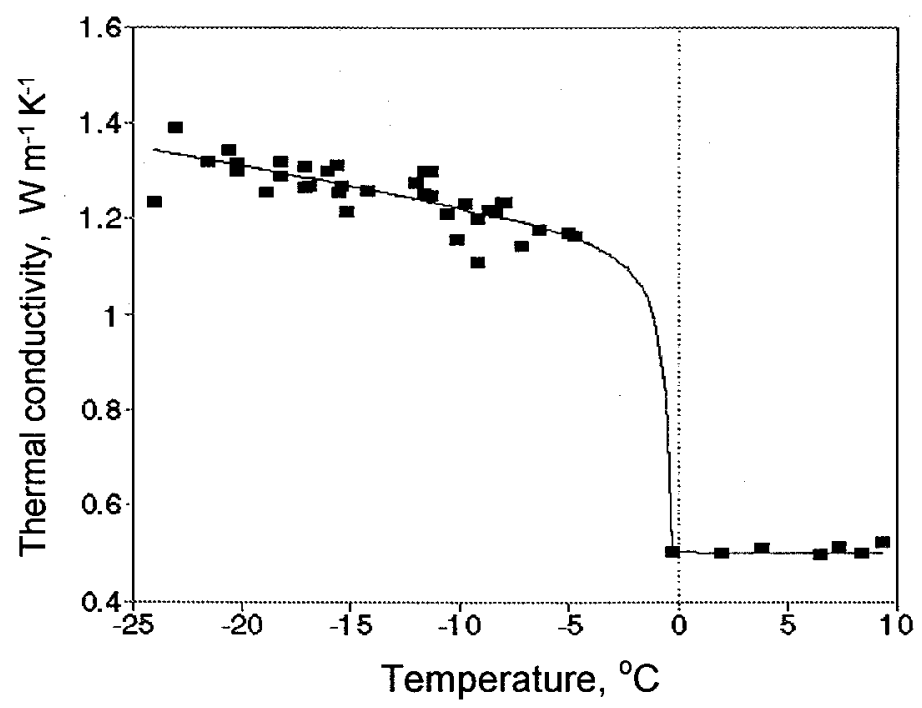

Fig. 1. Thermal conductivity of surimi with added $\kappa$-carrageenan $(w=8 \%)$. $\mathbf{\square}$ : experimental data; -: model data

The parameters of the Schwartzberg model for thermal conductivity (SCHWARTZBERG, 1977), $k_{\mathrm{f}}^{\prime}$ and $B$, were estimated by the least squares method from the linearized model expression given by:

$$
\left(k-k_{\mathrm{f}} \cdot \frac{T_{i}}{T}\right)=k_{\mathrm{f}}^{\prime} \cdot\left(1-\frac{T_{i}}{T}\right)+B \cdot\left(T_{i}-T\right)
$$

where $k_{\mathrm{f}}\left(\mathrm{W} \mathrm{m}^{-1} \mathrm{~K}^{-1}\right)$ and $B\left(\mathrm{~W} \mathrm{~m}^{-1} \mathrm{~K}^{-2}\right)$ are parameters in the regression of thermal conductivity; $k_{\mathrm{f}}\left(\mathrm{W} \mathrm{m}^{-1} \mathrm{~K}^{-1}\right)$ is thermal conductivity at $T_{i}$. In (6) $T_{\mathrm{i}}$ was determined from DTA and $k_{\mathrm{f}}$ was obtained by linear regression of the data above the initial freezing point. Values are given in Table 1 , but $k_{\mathrm{f}}$ for samples with different added substances levels were not statistically different. Standard deviation $\sigma$ for $k_{\mathrm{f}}$ for samples of surimi with added $\kappa$-carrageenan is $1.3 \%$ and for samples with $\mathrm{NaCl}$ is $1.1 \%$.

Obtained values of the thermal conductivity for samples of surimi with $\kappa$ carrageenan are in close agreement with data of WANG and KOLBE (1990). For example, for sample with $8 \% \mathrm{~K}$-carrageenan and $81.5 \%$ mass fraction of water standard deviation obtained in this work is $4.9 \%$. For samples with $8 \%$ mass fraction of added substances and $80.3 \%$ of water WANG and KOLBE report average standard deviation of $5.9 \%$. 
Table 1

Values of $k_{f}\left(W^{-1} K^{-1}\right)$ for samples of surimi with different mass fractions of the added substances

\begin{tabular}{ccc}
\hline $\begin{array}{c}\text { Mass fractions of added } \\
\text { substances w, \% }\end{array}$ & $k_{\mathrm{f}}, \mathrm{W} \mathrm{m}^{-1} \mathrm{~K}^{-1}$ & \\
\hline 0 & Surimi + -carrageenan & Surimi + NaCl \\
1 & 0.499 & 0.511 \\
2 & 0.506 & 0.499 \\
3 & 0.505 & 0.504 \\
4 & 0.511 & 0.497 \\
5 & 0.509 & 0.507 \\
6 & 0.497 & 0.499 \\
7 & 0.506 & 0.506 \\
8 & 0.512 & 0.499 \\
9 & 0.501 & 0.494 \\
10 & 0.495 & 0.487 \\
& 0.509 & 0.510 \\
\hline
\end{tabular}

Regression analysis was performed in two stages. First the parameters $k_{\mathrm{f}}^{\prime}$ and $B$ were estimated from experiments with each mass fraction of the added substances. In the second stage the parameters were correlated with the mass fraction by the linear models:

$$
\begin{gathered}
k_{\mathrm{f}}^{\prime}=a_{0}+a_{1} \cdot w \\
B=b_{0}+b_{1} \cdot w
\end{gathered}
$$

where $a_{0}\left(\mathrm{~W} \mathrm{~m}^{-1} \mathrm{~K}^{-1}\right), a_{1}\left(\mathrm{~W} \mathrm{~m}^{-1} \mathrm{~K}^{-1}\right), b_{0}\left(\mathrm{~W} \mathrm{~m}^{-1} \mathrm{~K}^{-2}\right)$ and $b_{1}\left(\mathrm{~W} \mathrm{~m}^{-1} \mathrm{~K}^{-2}\right)$ are parameters in the regression of thermal conductivity; $w(\%)$ is mass fraction of the added substances. The estimates of the coefficients in the linear regressions (7) are given in Table 2.

The parameter $B$, which is related to the linear dependence of thermal conductivity on temperature, decreases with increasing mass fraction of $\kappa$-carrageenan and $\mathrm{NaCl}$ (Table 2) due to increased level of bound water (WANG \& KOLBE, 1990). It is in agreement with the prediction of $k$ values by equation (6), and is also illustrated in Fig. 2. Increase in mass fractions of the added substances on temperatures below $T_{i}$ resulted in the decrease of $k$ values of surimi. It may be interpreted as reaction of added substances with myofibril proteins of surimi and dipole water molecules, resulting in the increase of mass fraction of bound water, which is unfreezable in the measurement range of temperature from $-25^{\circ} \mathrm{C}$ to $T_{i}$. 
Table 2

Linear regression coefficients of the parameters $k_{f}^{\prime}$ and $B$ mass fraction of the added substances

\begin{tabular}{lcccc}
\hline $\begin{array}{c}\text { Added } \\
\text { substance }\end{array}$ & $a_{0}$ & $a_{1}$ & $b_{0}$ & $b_{1}$ \\
\hline K-carrageenan & 1.075 & 0.12063 & 0.01429 & -0.00487 \\
$\mathrm{NaCl}$ & 1.138 & 0.00733 & 0.01326 & -0.00079 \\
\hline
\end{tabular}

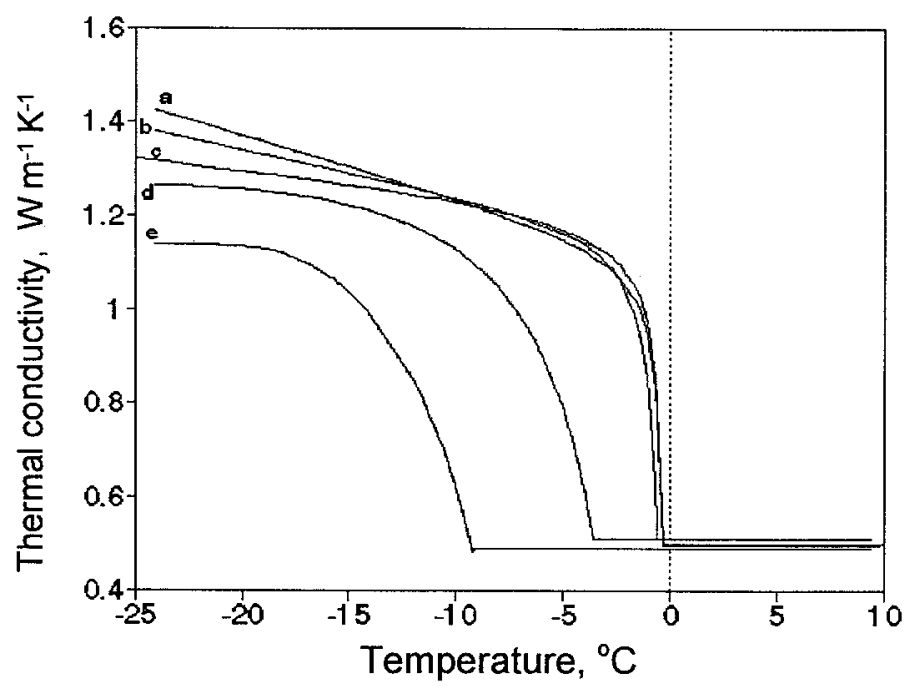

Fig. 2. Thermal conductivity of surimi with added $\kappa$-carrageenan and $\mathrm{NaCl}$. a: $w$ (added substances) $=0 \%$; b: $w(\kappa$-carrageenan $)=5 \% ; \mathrm{c}: w(\kappa$-carrageenan $)=9 \% ; \mathrm{d}: w(\mathrm{NaCl})=5 \% ; \mathrm{e}: w(\mathrm{NaCl})=9 \%$

Interaction of added substances with proteins is also demonstrated by data presented on Fig. 3. Comparison of the initial freezing points $T_{i}$ for samples of surimi and water solution of $\mathrm{NaCl}$ and $\kappa$-carrageenan as a function of mass fraction of $\mathrm{NaCl}$ and $\kappa$-carrageenan calculated on total mass of water show differences, which supports the assumption of essential interactions of added substances and myofibril proteins. 


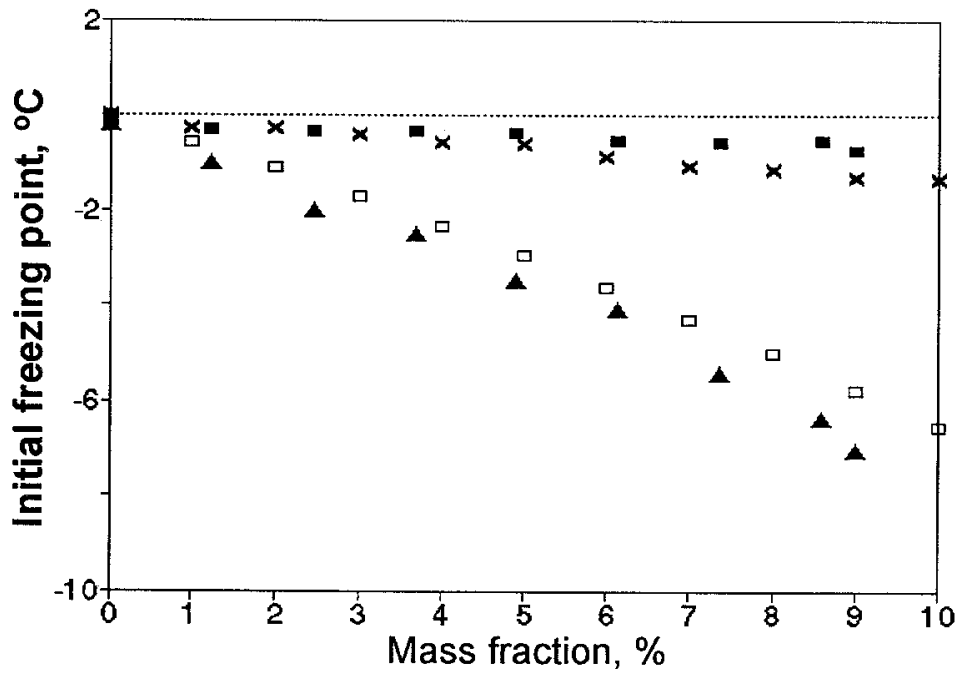

Fig. 3. Comparison of depedencies of $T_{i}$ for surimi and water solution of $\mathrm{NaCl}$ and $\mathrm{\kappa}$-carrageenan on mass fraction $w$ of added substances calculated on total mass of water. $\square$ : Surimi $+\kappa$-carrageenan; - : surimi $+\mathrm{NaCl}$; X: water solution of $\kappa$-carrageenan; $\square$ : water solution of $\mathrm{NaCl}$

From DTA diagrams the peak points were read off as the initial freezing temperatures. Data for the initial freezing points were reported by KovAČEVIĆ \& KURTANJEK (2000). Values of the initial freezing points $T_{i}$ were applied in the models for calculation of $\rho, k$ and $\bar{H}$.

The relative apparent specific enthalpies were measured in the temperature range from $-25^{\circ} \mathrm{C}$ to $T_{i}$ and are presented as continuous curves as function of the sample temperatures (Figs 4 and 5). The given values are apparent enthalpies resulting from sensible enthalpy (related to temperature) and phase transformation (latent heat). The obtained results for enthalpy are also verified by an independent experimental method, i.e. by differential scanning calorimetry (DSC) measurements conducted by WANG and KOLBE (1991). In Fig. 4 experimental values for enthalpy determined by DTA are given for surimi samples without the cryoprotecting mixture, together with correlation data from the ChANG and TAO (1981) and Dickerson data (HELDMAN, 1981). 
The Chang-Tao model is given by:

$$
\begin{aligned}
& H_{\mathrm{r}}=b_{1} \cdot\left(T_{\mathrm{r}}+273.15\right)+\left(1-b_{1}\right) \cdot T_{\mathrm{r}}^{\mathrm{b}_{2}} \\
& H_{\mathrm{r}}=\frac{H}{H_{\mathrm{i}}} T_{\mathrm{r}}=\frac{(T+273.15)-227.6}{\left(T_{i}+273.15\right)-227.6}
\end{aligned}
$$

where $H_{\mathrm{i}}\left(\mathrm{kJ} \mathrm{kg}^{-1}\right)$ is specific enthalpy at $T_{i}$. The parameter values $b_{1}=0.295$ and $b_{2}=22.455$ were recalculated by the models proposed for meat group products with experimentally determined mass fraction of water in surimi samples. Data by Dickerson are taken from the table (HELDMAN, 1981) for fish and cod meat. When the specific enthalpy curve determined by DTA is compared with the literature data, it can be observed that enthalpies are in very good qualitative and quantitative agreement with data. For example, measured value of specific enthalpy in the temperature range from $-25{ }^{\circ} \mathrm{C}$ to $T_{i}$ for sample without added substance is $244 \mathrm{~kJ} \mathrm{~kg}^{-1}$, while WANG and KOLBE (1991) have obtained $242 \mathrm{~kJ} \mathrm{~kg}^{-1}$.

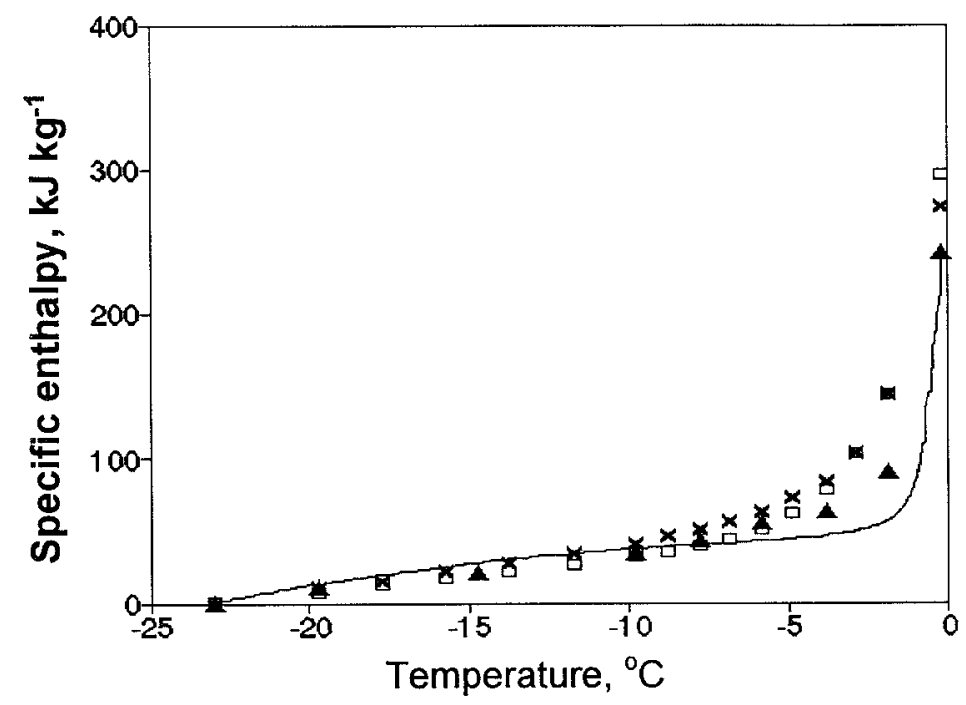

Fig. 4. Relative apparent specific enthalpy of surimi without added substances measured by DTA, compared with data from literature. -: Measured data; - : WANG \& Kolbe data; $\square$ : CHANG \& TAO model; $\mathrm{X}$ : Dickerson data 


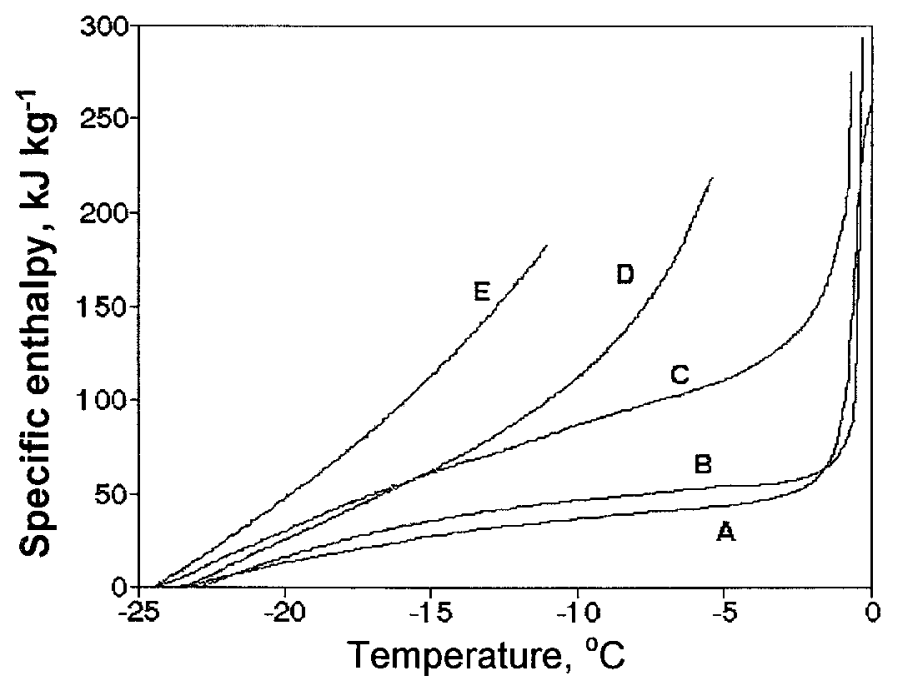

Fig. 5. Comparison of relative apparent specific enthalpy for samples of surimi with different mass fractions

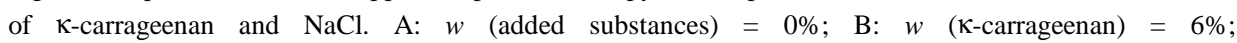
$\mathrm{C}: w(\kappa$-carrageenan $)=10 \% ; \mathrm{D}: w(\mathrm{NaCl})=6 \% ; \mathrm{E}: w(\mathrm{NaCl})=10 \%$

Results show change in relative apparent specific enthalpy, i.e. increase at lower temperatures with increased mass fraction of the added substances. From comparison of effects of $\mathrm{NaCl}$ and K-carrageenan on specific enthalpy $\bar{H}$, presented in Fig. 5, it is evident that samples with added $\mathrm{NaCl}$ have higher values of $\bar{H}$ at the same values of mass fractions of the added substance $w$ and temperature $T$. It is the result of stronger effect of $\mathrm{NaCl}$ on cryoscopic depression of $T_{i}$, i.e. nucleation and crystal growth are depressed to lower temperatures. During thawing process such samples absorb more latent heat, which results in the increase of apparent specific enthalpy $\bar{H}$ at lower temperatures.

\section{Conclusions}

Quantitative treatment of DTA curves (by use of collocation technique) has provided enthalpies of surimi in the temperature range from $-25^{\circ} \mathrm{C}$ to initial freezing points $T_{i}$. Relative apparent specific enthalpy $\bar{H}$ determined by DTA was verified by data from correlation models based on calorimetric measurements. The results show the 
effect of added substances $\mathrm{NaCl}$ and $\kappa$-carrageenan on thermal properties which, are due to their interaction with myofibril proteins in surimi samples. Thermal conductivity $k$ and apparent specific enthalpy $\bar{H}$ are functions of mass fractions of added substances. In the measured temperature interval from $-25^{\circ} \mathrm{C}$ to $T_{i}$ increase in mass fractions of added substances results in the increase of the amount of bound (unfreezable) water, lowers initial freezing point $T_{i}$, decreases thermal conductivity $k$ and increases apparent specific enthalpy $\bar{H}$. These effects are more pronounced for samples with added $\mathrm{NaCl}$.

$*$

This work was financially supported by the Ministry of Science and Technology, Republic of Croatia, project 058201 . Authors express their appreciation to Prof. V. E. SWEAT for providing the line source heating element.

\section{References}

A.O.A.C. (1980): Official methods of analysis. 13th ed., A.O.A.C. Intl., Arlington, Virginia, pp. 275-376

Chang, H. D. \& TAO, L. C. (1981): Correlation of enthalpies of food systems. J. Fd Sci., 46, 1493-1497.

Cunninham, A. D. \& Wilburn, F. W. (1970): Theory. -in: MacKenzie, R. C. (Ed) Differential thermal analysis. (Vol. I). Academic Press, London-New York, pp. 59-62.

FindLay, C. J. \& BARBut, S. (1990): Thermal analysis of meat. -in: HARWALKaR, V. R. \& MA, C. Y. (Eds) Thermal analysis of foods. Elsevier Applied Science, London \& New York, pp. 92-126.

HeLDMAN, D. R. (1981): Food process engineering. AVI Publising Co. Inc., Wesport, CN, p. 404.

IBELE, W. (1973): Thermophysical properties. -in: ROHSENOW, W. M. \& HARTNETT, J. P. (Eds) Handbook of heat transfer. McGraw Hill, New York, pp. 2-70.

KOVAČEvIĆ D. \& KURTANJEK, Ž. (1993): Odredivanje entalpije smrznutog iskoštenog ribljeg mesa (surimija) diferencijalnom termičkom analizom. (Enthalpy determination of frozen surimi by differential thermal analysis.) Prehrambeno-tehnol. biotehnol. rev., 31, 157-164.

KovaČEviĆ D. \& KURTANJEK, Ž. (1995): Mjerenje i modeliranje toplinske vodljivosti zamrznutih surimija. (Measurement and modeling of thermal conductivity of frozen surimi). Prehrambeno-tehnol. biotehnol. rev., 33, 31-36.

KOVAČEVIĆ D. \& KURTANJEK, Ž. (2000): Effect of K-carrageenan and $\mathrm{NaCl}$ on initial freezing point of food. Acta Alimentaria, 29, 335-344.

LEE, C. M. (1984): Surimi process technology. Fd Technol., 38 (11), 69-72.

Murakami, E. G., Sweat, V. E., Sastry, S.K., Kolbe, E., Hayakawa, K. \& Datta, A. (1995): Recommended design parameters for thermal conductivity probes for nonfrozen food materials. $J$. Fd Engng., 27, 109-123.

Murakami, E. G., Sweat, V. E., Sastry, S.K. \& Kolbe, E. (1996): Analysis of various design and operating parameters of the thermal conductivity probe. J. Fd Engng., 30, 209-225.

REIDI, G. A. \& RIPEN, A. L. (1971): Methods for determining thermal conductivity in foods. ASAE Trans., 14, 248-254.

SCHWARTZBERG, H. G. (1977): Effective heat capacities for the freezing and thawing of foods. Proc. of IIR, Karlshruhe, pp. 303-305. 
SUCCAR, J. (1985): Estimation of thermophysical properties of food at freezing temperatures. Tran. ASAE, V91, Part 2B: 312-332.

SwEAT, V.E. (1986): Thermal properties of foods. -in: RAO, M. A. \& RIZVI, S. S. H. (Eds) Engineering properties of foods. Marcel Dekker, New York, pp. 49-61.

SwEAT, V. E. \& HAUGH, C. G. (1974): A thermal conductivity probe for small food samples. ASAE Trans., $17(1), 56-58$.

SZCZESNIAK, A. S. (1983): Physical properties of foods: what they are and their relation to other food properties. -in: PelEg, M. \& BAgley, E. B. (Eds) Physical properties of foods. AVI Publishing Co., Westport, CT, pp. 7-16.

Sych, J., Lacroix, C., Adambounou, L. T. \& Castaigne, F. (1990): Cryoprotective effects of lactitol, palatinit and polydextrose on Cod surimi proteins during frozen storage. J. Fd Sci., 55, 356-360.

TAIT, R. W. F. \& HILls, B. A. (1964): Methods for determining liquid thermal conductivities. Ind. Engng Chem., 56 (7), 29-35.

WANG, D. Q. \& KolBE, E. (1990): Thermal conductivity of surimi-measurement and modeling. J. Fd Sci., $55,1217-1221$.

WANG, D. Q. \& Kolbe, E. (1991): Thermal properties of surimi analyzed using DSC. J. Fd Sci., 56, 302-308. 